\title{
Volatile Organic Compounds in Ground Water of the Lower Illinois River Basin
}

\author{
By William S. Morrow, Jr.
}

\begin{abstract}
Water samples collected from 60 wells in the lower IIInois River Basin (LIRB) in 1996 were sampled and analyzed for 73 volatile organic compounds (VOC's). There were only six VOC detections in more than 4,300 analyses of the ground-water samples: three detections of chloroform, one detection of carbon tetrachloride, one detection of methyl tert-butyl ether (MTBE), and one detection of 1,2,3,4-tetramethyl benzene (TeMB). VOC concentrations ranged from 0.22 to 4.7 misnograms per liter (ug/L), with only one VOC concentration greater than $1 \mu \mathrm{g} / \mathrm{L}$. A VOC was detected in one sample from the deep glacial drift aquifer, indicating that shallow aquifers may be more susceptible to VOC contamination than deep aquifers.
\end{abstract}

\section{INTRODUCTION}

In 1991, the U. S. Geological Survey (USGS) implemented the full-scale National Water-Quality Assessment (NAWQA) program to assess the quality of the Nation's ground- and surface-water resources, characterize the trends in the quality of these resources, and identify natural and anthropogenic factors that affect water quality. The lower Illinois River Basin (LIRB) (fig. 1) is one of 59 study units throughout the Nation in which water-quality data are being collected by the NAWQA program to assess water quality at a regional and national level. In the LIRB, a general concern is ground-water-quality conditions; and because of increasing urbanization in the basin, a growing concern is the potential occurrence of volatile organic compounds (VOC's) in the aquifer system underlying the LIRB. Hydrogeomorphically and agriculturally similar basins in the Midwest, such as the White River Basin in Indiana, indicate that urban areas have substantially more VOC detections than agricultural areas.

The purpose of this report is to present the results of ground-water sampling and analysis for VOC's in the LIRB. To determine the concentration of 73 VOC's, 60 randomly selected wells were sampled (table 1). The analyses for these compounds were censored to a 0.20 micrograms per liter $(\mu \mathrm{g} / \mathrm{L})$ reporting level. In more than 4,300 laboratory analyses, only six detections of four different VOC's were identified, indicating VOC contamination, at present (1996), is not a major concern in the LIRB.

The lower Illinois River Basin, covering an area of 18,000 square miles in western and central Illinois, consists of the drainage area from Ottawa, Ill, to the confluence of the Illinois and Mississippi Rivers at Grafton, Ill. (fig. 1). The primary land use is agricultural - mostly corn and soybeans. The largest population centers in the basin are Peoria, Springfield, Bloomington-Normal, and Decatur. The major aquifers underlying the basin are composed of glacial deposits of Quaternary age and Pennsylvanian- to Mississippian-age bedrock. Some major Quaternary aquifers are present in buried bedrock valleys (Warner and Schmidt, 1994).

Appreciation is extended to the private well owners in the LIRB who gave permission to sample their wells.

\section{DESCRIPTION OF AQUIFERS}

Wells completed in two aquifers of Quaternary age were sampled for VOC analyses. One aquifer is the deep glacial drift aquifer in the Mahomet buried bedrock valley in the Bloomington Ridged Plain, which is overlain by Wisconsinan glacial deposits. The other aquifer is the shallow glacial drift aquifer in the Galesburg/Springfield Plain not overlying a buried bedrock valley (Galesburg/Springfield Plain) (fig 2). The Galesburg/Springfield Plain is surficially covered by Illinoian glacial deposits with more rugged topography than the Bloomington Ridged Plain, reflecting the greater age of the Galesburg/Springfield Plain deposits. 


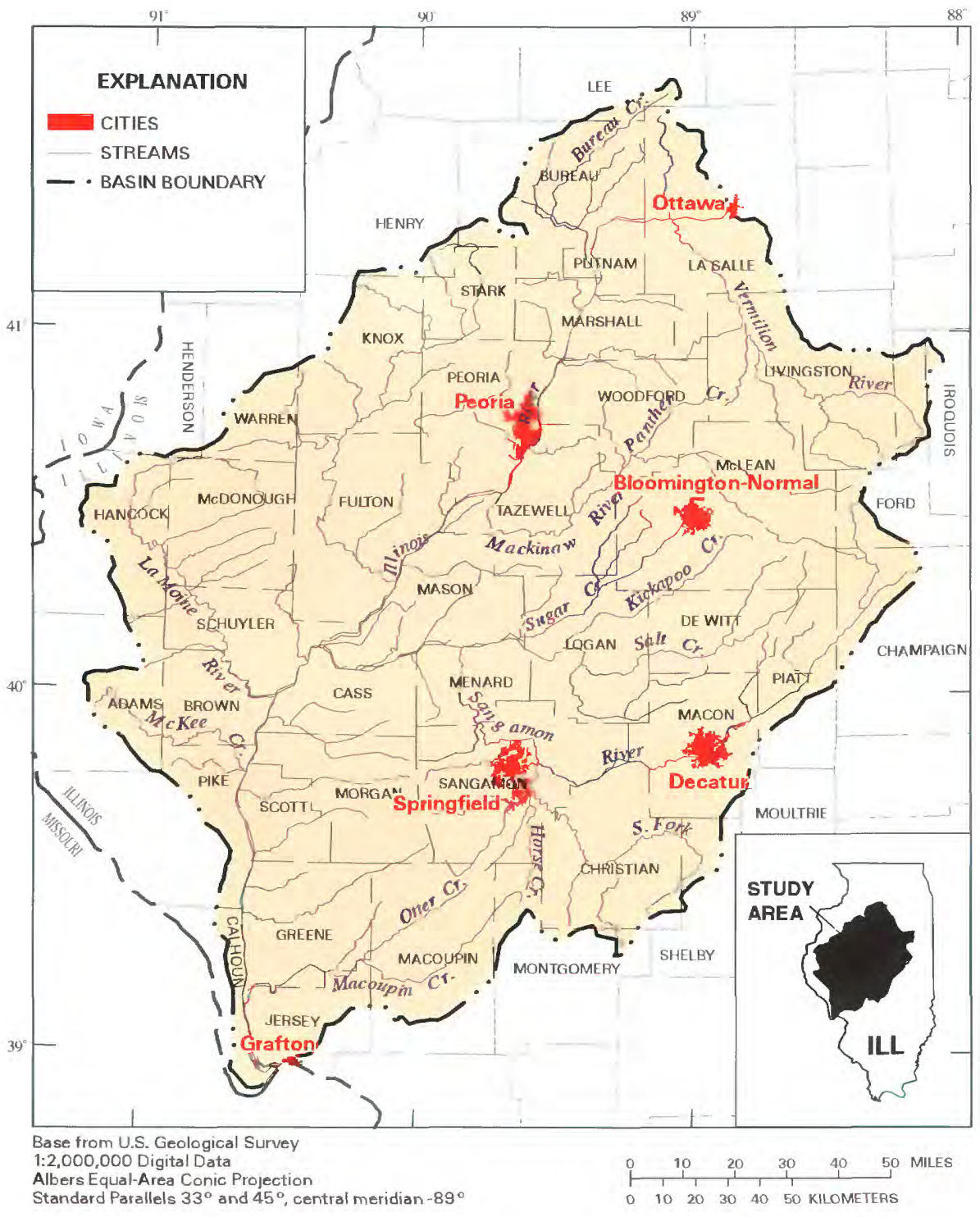

Figure 1. Location of lower Illinois River Basin in Illinois.

The deep glacial drift aquifer in the Mahomet buried bedrock valley is the largest source of ground water for irrigation, industrial, and municipal water supplies in east-central Illinois. At least 40 municipalities and water districts withdraw water from this aquifer (Kempton and others, 1991). The aquifer lies in a buried bedrock valley near the eastern edge of the basin and trends towards southeastern Tazewell County in the center of the basin (fig. 2), where it joins another buried bedrock valley beneath the Illinois River. The aquifer underlies approximately 6 percent of the LIRB area. The aquifer comprises primarily pre-Illinoian glacial deposits and is overlain by Wisconsinan glacial deposits. Confining clays and silts in the Wisconsinan, Illinoian, and pre-Illinoian drift overlying the deep glacial drift aquifer are commonly greater than 100 feet thick.

For this report, the shallow glacial drift Galesburg/Springfield Plain aquifer comprises Illinoian glacial deposits in the southern and western areas of the basin that do not overlie buried valleys. This aquifer underlies approximately 42 percent of the LIRB area. The water-producing units of the aquifer tend to be relatively thin and discontinuous; as a result, the shallow glacial drift aquifer is used primarily for single-household private-water supply. Wells are usually screened in thin sandand-gravel units of the Illinoian drift, which commonly are overlain by confining clays and silts.

\section{STUDY METHODS}

Wells completed in glacial drift and constructed after 1980 (to ensure that they had been installed using modern well-construction techniques) were selected for sampling using a computerbased random site-selection method developed by Scott (1990). Of the 60 wells sampled, 59 were privatesupply wells and 1 was a public-supply well. All wells were in rural areas. Samples were obtained prior to passing through residential water-treatment systems to avoid chemical modifications introduced by these systems.

Thirty of the wells sampled were screened in the deep glacial drift aquifer within the Mahomet buried bedrock valley area, where the top of bedrock was below 500 feet above sea level in altitude. Wells selected were 200 feet or greater in depth. The well diameters were either 4 or 5 inches; 80 percent were 5 inches in diameter. Well-screen lengths ranged from 4 to 12 feet, with a median screen length of 5.5 feet. Well depths ranged from 200 to 365 feet below land surface, with a median depth of 256 feet. The locations of the sampled wells are shown in figure 2.

The remaining 30 wells sampled were screened in the shallow glacial drift aquifer in the Galesburg/Springfield Plain. Selected wells were 110 feet or less in depth. Well diameters in the shallow glacial drift aquifer ranged from 5 to 36 inches: 55 percent were 36 inches in diameter. The largediameter wells were constructed because small-diameter wells are usually not capable of producing a 
Table 1. Volatile organic compound target analytes in the lower Illinois River Basin with a method reporting level of 0.20 micrograms per liter

International Union of Pure and Applied Chemistry (IUPAC) volatile organic compound name

Compound
Benzene
Bromobenzene
Bromochloromethane
Bromodichloromethane
Bromoethene
Bromomethane
Carbon disulfide
Chlorobenzene
Chlorodibromomethane
Chloroethane
Chloroethene
Chloromethane
cis-1,2-Dichloroethene
cis-1,3-Dichloropropene
Dibromomethane
Dichlorodifluoromethane
Dichloromethane
Diethyl ether
Ethyl tert-butyl ether
Ethylbenzene
Hexachlorobutadiene
Hexachloroethane
Iodomethane
Isopropylbenzene
Methyl tert-butyl ether
Methylbenzene
Naphthalene
$n$-Butylbenzene
$n$-Propylbenzene
p-Isopropyltoluene
sec-Butylbenzene
Styrene
tert-Amyl methyl ether
tert-Butylbenzene
Tetrachloroethene
Tetrachloromethane
trans-1,2-Dichloroethene

domestic water supply from the thinner and less permeable water-producing units in the area. Well-screen lengths ranged from 0 to 78 feet, with a median screen length of 26 feet. Well depths ranged from 30 to 108 feet, with a median depth of 50 feet.

Samples were obtained through the existing submersible pump and collected for laboratory analyses after $\mathrm{pH}$, dissolved oxygen, water temperature, and turbidity readings had stabilized. The readings usually stabilized after three well volumes were purged or, in the case of the 36-inch diameter wells, 2 hours of purge time had elapsed. Samples were collected in 40-milliliter vials using Teflon ${ }^{1}$ and

\begin{tabular}{l} 
Compound \\
trans-1,3-Dichloropropene \\
Tribromomethane \\
Trichloroethene \\
Trichlorofluoromethane \\
Trichloromethane \\
1,1,1,2-Tetrachloroethane \\
1,1,1-Trichloroethane \\
1,1,2,2-Tetrachloroethane \\
1,1,2-Trichloro-1,2,2-trifluoroethane \\
1,1,2-Trichloroethane \\
1,1-Dichloroethane \\
1,1-Dichloroethene \\
1,1-Dichloropropene \\
1,2,3,4-Tetramethylbenzene \\
1,2,3,5-Tetramethylbenzene \\
1,2,3-Trichlorobenzene \\
1,2,3-Trichloropropane \\
1,2,3-Trimethylbenzene \\
1,2,4-Trichlorobenzene \\
1,2,4-Trimethylbenzene \\
1,2-Dibromoethane \\
1,2-Dichlorobenzene \\
1,2-Dichloroethane \\
1,2-Dichloropropane \\
1,2-Dimethylbenzene \\
1,3,5-Trimethylbenzene \\
1,3-Dichlorobenzene \\
1,3-Dichloropropane \\
1,3-Dimethylbenzene \\
1,4-Dichlorobenzene \\
1,4-Dimethylbenzene \\
2,2-Dichloropropane \\
2-Chlorotoluene \\
2-Ethyltoluene \\
3-Chloro-1-propene \\
4-Chlorotoluene \\
\hline
\end{tabular}

stainless-steel sampling equipment, preserved with hydrochloric acid to a $\mathrm{pH}$ of less than 2, chilled, and shipped the day of sampling to the USGS National Water Quality Laboratory (NWQL) in Arvada, Colorado. Samples for each well were analyzed for 73 VOC's by purge-and-trap isolation and concentration, and capillary-column gas chromatography/ mass spectrometry methods (Rose and Schroeder, 1995). VOC data were censored to a previously approved reporting level of $0.20 \mu \mathrm{g} / \mathrm{L}$ because

\footnotetext{
${ }^{1}$ Any use of trade, product, or firm names is for descriptive purposes only and does not imply endorsement by the U.S. Government.
}

the analytical method was provisional at the time of data collection.

A quality-assurance program consisting of blanks, replicates, and spikes in the field and laboratory was developed to evaluate the bias and variability of the analytical results (Koterba and others, 1995; Rose and Schroeder, 1995). To determine the quality of the data, 24 quality-assurance samples were collected, including 9 field blanks and 4 replicate spikes. Data were determined to be of satisfactory quality, with the following exceptions: tetrachloroethene (tetrachloroethylene) results were deleted from 31 of 60 samples because it was determined that contamination was introduced in the sampling process, and dichloromethane (methylene chloride) results also were deleted from 6 of 60 samples because similar concentrations were measured in field blanks and environmental samples.

\section{DETECTIONS OF VOLATILE ORGANIC COMPOUNDS}

In more than 4,300 analyses, six VOC's were detected in samples obtained from five wells (fig. 2). There were three detections of trichloromethane (chloroform), one detection of methyl tert-butyl ether (MTBE), one detection of tetrachloromethane (carbon tetrachloride), and one detection of 1,2,3,4-tetramethyl benzene (TeMB). Five of the six detections were in samples from wells screened in the shallow glacial drift aquifer. None of the detections exceeded any applicable U.S. Environmental Protection Agency (USEPA) drinking-water standards (U.S. Environmental Protection Agency, 1996).

Chloroform was detected most frequently, with three detections at concentrations of $0.31,0.37$, and $4.7 \mu \mathrm{g} / \mathrm{L}$; all detections were in samples from the shallow glacial drift aquifer. Chloroform $\left(\mathrm{CHCL}_{3}\right)$ belongs to a class of VOC's known as trihalomethanes (THM's), a group of compounds that also includes 


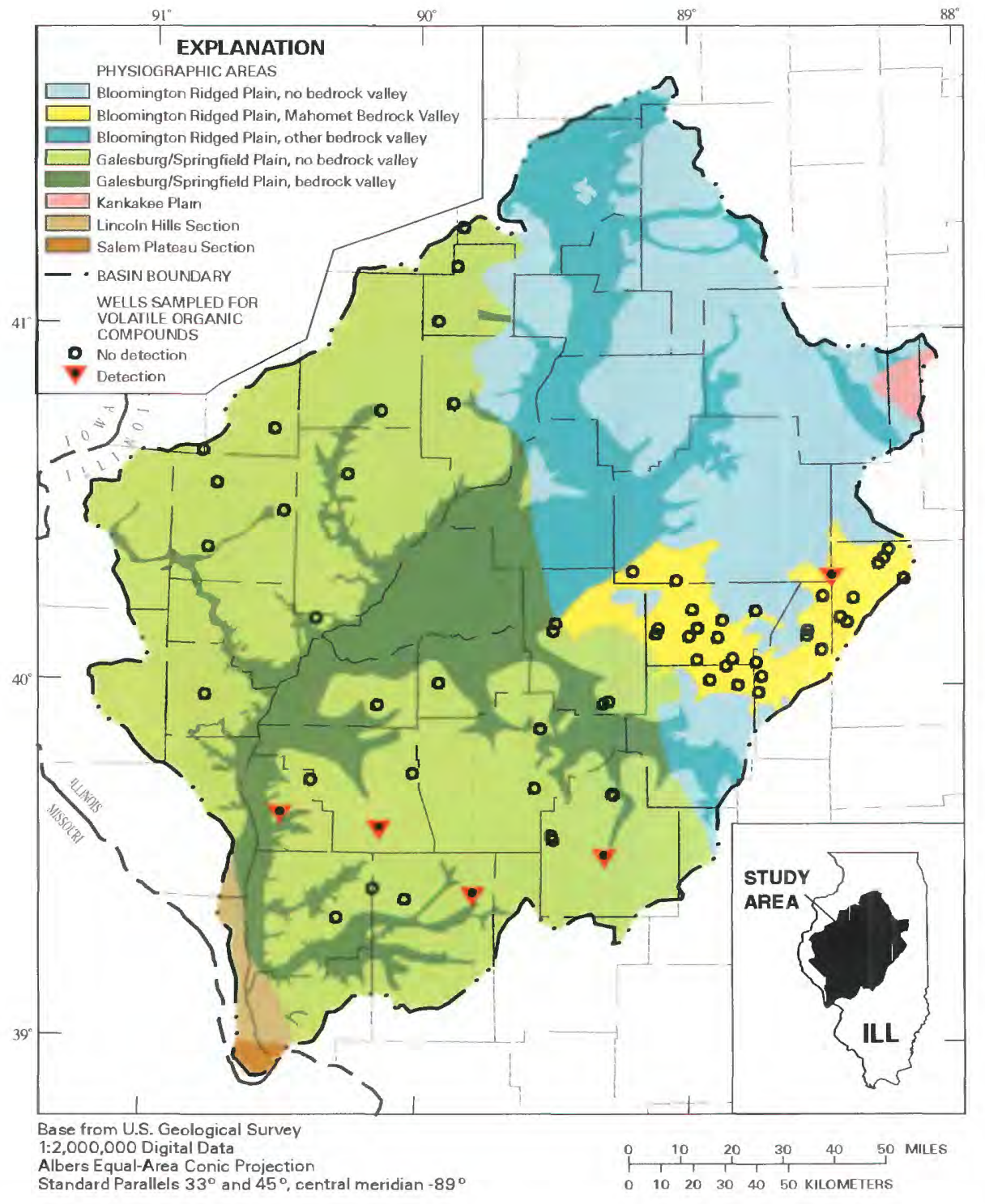

Figure 2. Physiographic areas of the lower Illinois River Basin and location of wells sampled for volatile organic compounds.

bromodichloromethane $\left(\mathrm{CHBrCl}_{2}\right)$, dibromochloromethane $\left(\mathrm{CHBr}_{2}\right)$, and bromoform $\left(\mathrm{CHBr}_{3}\right)$. THM's are commonly produced by the chlorination of water containing dissolved organic matter. At present, the USEPA maximum contaminant level (MCL) for the sum of all THM concentrations (total trihalomethanes) in drinking water is $100 \mu \mathrm{g} / \mathrm{L}$ (U.S. Environmental Protection Agency, 1996). Neither bromoform, bromodichloromethane, nor dibromochloromethane were detected in any samples at concentrations at or above $0.20 \mu \mathrm{g} / \mathrm{L}$. Chloroform can result from sources such as pulp, paper, chemical, or pharmaceutical manufacturing processes. In the private-supply wells sampled here, chloroform is likely a by-product of previous chlorination, or "bleaching", of the domestic well for disinfection purposes (Illinois Department of Public Health, 1998) - a practice commonly carried out by adding household bleach to the well to control bacterial growth.

MTBE, a fuel oxygenate added to gasoline to increase the octane level (as well as to decrease vehicle carbon monoxide emissions and ozone levels), was detected at a concentration of $0.59 \mu \mathrm{g} / \mathrm{L}$ in one sample from a well screened in the shallow glacial drift aquifer. MTBE has a drinking-water advisory level of $20-40 \mu \mathrm{g} / \mathrm{L}$ (U.S. Environmental Protection Agency, 1997). MTBE is a water-soluble compound that is being detected with increasing frequency in ground water in the Nation as a result of both point and nonpoint sources, such as atmospheric precipitation (Delzer and others, 1996). Other potential sources less than 100 meters from the well include a public roadway and a small lake that has limited motorized-watercraft use. MTBE has statewide use in Illinois as an octane booster: however, ethanol is the primary fuel oxygenate used in Illinois. Approximately 70 percent of all gasoline in the United States contains varying amounts of MTBE (U.S. Environmental Protection Agency, 1998). Throughout Illinois, MTBE is added to gasoline as an octane booster, but ethanol is the primary fuel oxygenate used in the State.

Carbon tetrachloride, which has an MCL of $5 \mu \mathrm{g} / \mathrm{L}$ (U.S. Environmental Protection Agency, 1996), was detected at a concentration of $0.24 \mu \mathrm{g} / \mathrm{L}$ in one sample from the shallow glacial drift aquifer. Chloroform also was detected in this sample at a concentration of $4.7 \mu \mathrm{g} / \mathrm{L}$. Carbon tetrachloride is a polychlorinated methane, as is chloroform, and is used in the manufacture of refrigerant gases, solvents, agrichemicals, and fumigants. The carbon tetrachloride probably was not derived from a septic system because the concentrations of dissolved nitrates (3.6 milligrams per liter $(\mathrm{mg} / \mathrm{L}))$ and dissolved phosphate $(0.01 \mathrm{mg} / \mathrm{L})$ at this well were lower than would have been expected for septic-system-derived contamination. Instead, the detection of carbon tetrachloride may have been related to the use of bleach as a well-disinfecting agent. The addition of bleach to the well some time prior to sampling was confirmed with the well owner. Halogenated alkanes may have been 
present in the bleach used for disinfecting, as commercial chlorine can contain carbon tetrachloride, in addition to other chlorinated and nonchlorinated chemical impurities (Christman, 1980).

TeMB, which has no drinking-water regulatory limits at present (U.S. Environmental Protection Agency, 1996), was detected at a concentration of $0.22 \mu \mathrm{g} / \mathrm{L}$ in one sample from the deep glacial drift aquifer. TeMB is not commonly used at the present time for commercial purposes, and its source is unknown.

Between 1985 and 1995, an assessment of VOC occurrence in untreated ground water in the conterminous United States was conducted on 2,948 rural and urban wells for 60 VOC's. The reporting level was $0.2 \mu \mathrm{g} / \mathrm{L}$ except for 1,2-dibromo-3chloropropane, which was $1.0 \mu \mathrm{g} / \mathrm{L}$. VOC's were detected in 14 percent of the 2,542 rural area wells. MTBE accounted for 4.8 percent of the VOC detections. Solvents, refrigerants, and synthetic organic compounds were the majority of VOC's detected, accounting for 76 percent of the detections. Gasoline aromatic hydrocarbons and fumigants also were present (Squillace and others, in press).

To put the LIRB results into a Midwest perspective, LIRB data were compared with data from the agriculturally and hydrogeomorphically similar White River Basin in Indiana. In the White River Basin, VOC data were collected in urban and in agricultural areas during 1994-95 from monitoring wells completed in glacial and fluvial deposits similar to those in the LIRB. Samples from 66 agricultural wells in the White River Basin were analyzed for 58 VOC's at a reporting level of $0.2 \mu \mathrm{g} / \mathrm{L}$ except for 1,2-Dibromo-3chloropropane, which had a $1.0 \mu \mathrm{g} / \mathrm{L}$ reporting level (Fenelon and Moore, 1996). The VOC's analyzed from the White River Basin were similar to those analyzed in the LIRB samples; however, some compounds were not included, notably TeMB, which was detected in the LIRB.

All VOC detections in the White River Basin were in ground water underlying the glacial till plain. Of the 66 sampled wells overlying agricultural areas, four ( 6 percent) had detections. Three compounds-chloroform, methylene chloride, and MTBEwere detected. Maximum concentrations were chloroform $(1.7 \mu \mathrm{g} / \mathrm{L})$, methylene chloride $(0.81 \mu \mathrm{g} / \mathrm{L})$, and MTBE $(0.35 \mu \mathrm{g} / \mathrm{L})$ (Fenelon and Moore, 1996). Methylene chloride was deleted from the LIRB data set due to sample contamination problems. Chloroform and MTBE also were detected in the LIRB and also had the highest concentrations of detected VOC's.

The White River Basin and the LIRB showed many similarities in the VOC analyses of samples from wells in agricultural settings. Many VOC's were analyzed with the same reporting level of $0.2 \mu \mathrm{g} / \mathrm{L}$ in both basins. A similar percentage of wells had VOC detections, with 8 percent in the LIRB compared with 6 percent in the White River Basin. Results also were similar for chloroform and MTBE, which were detected in both studies, but at concentrations far below regulatory levels. Carbon tetrachloride and TeMB also were detected in the LIRB. The chloroform and MTBE detections indicate other agricultural settings in glacial till areas may show similar levels of VOC's.

Wells in urban areas of the White River Basin also were sampled for analysis of VOC's. These compounds were detected in slightly more than one-half of the samples from 25 urbanarea wells, and 12 different VOC's were detected at concentrations above the reporting level. Chloroform was the most frequently detected compound (in 40 percent of the wells), at a maximum concentration of $21 \mu \mathrm{g} / \mathrm{L}$. If the results of the White River Basin urban-area well study are presumed to be typical, the results indicate that wells in urban areas in similar glacial hydrogeomorphological settings are more susceptible to VOC contamination than are wells in agricultural areas.

VOC's were detected in 8 percent of the 60 wells sampled in the LIRB. By comparison, VOC's were detected in 5 percent of the wells sampled in a statewide study by the Illinois Environmental Protection Agency (IEPA) (1996). Fewer than 25 VOC's, primarily chlorinated solvents, THM's, and fuel compounds, were analyzed in the statewide study. The analyses included chloroform and carbon tetrachloride but did not include MTBE or TeMB. The reporting level for the IEPA analyses was $1 \mu \mathrm{g} / \mathrm{L}$ (Illinois Environmental Protection Agency, 1991), which is five times higher than the level used in the LIRB described in this report. If the LIRB study used a reporting level of $1 \mu \mathrm{g} / \mathrm{L}$, only one compound (chloroform at a concentration of $4.7 \mu \mathrm{g} / \mathrm{L}$ ) would have been detected in the LIRB. Trichloroethene was the most common VOC detected in the community-supply wells sampled in the IEPA study. By contrast, chloroform was the most frequently detected VOC during the LIRB study, and organic solvents were virtually absent. The IEPA detections may reflect the type of wells sampledpublic-supply wells near high-density populated areas and related sources and potential industrial solvent sources. The disinfection procedures used by well owners in the private-supply wells sampled for the LIRB study may account for the relatively higher chloroform detections.

\section{SUMMARY}

As part of the NAWQA program of the U.S. Geological Survey (USGS), water samples from 60 wells in the lower Illinois River Basin (LIRB) were analyzed for 73 volatile organic compounds (VOC's). On the basis of a reporting level of $0.20 \mu \mathrm{g} / \mathrm{L}, \mathrm{VOC}$ 's were detected in only six of more than 4,300 analyses. Four different VOC's 
were detected in samples taken from five wells. At least three of these detections may be the result of well disinfection practices, resulting in the formation of chloroform. Carbon tetrachloride, detected near the reporting level, also may have been present because of the use of bleach as a well disinfectant. Another compound detected near the reporting level, TeMB, has no current known uses. MTBE, a common fuel oxygenate, also was detected at a concentration of less than $1 \mu \mathrm{g} / \mathrm{L}$. Five of the six detections were in samples from wells completed in the shallow glacial drift aquifer in the Galesburg/Springfield Plain. Only one detection was for a sample from the deep glacial drift aquifer, indicating shallow aquifers may be more susceptible to VOC contamination than deep aquifers in the LIRB. Based on these results, VOC contamination does not appear to be a major concern at present (1996) with respect to groundwater quality in rural areas of the LIRB.

\section{REFERENCES}

Christman, R.F., 1980, Chemistry of the use of chlorine in water and food processing in Jolley, R.L., Brungs, W.A., and Cumming, R.B., eds., Water chlorination, environmental impact and health effects, Volume 3: Ann Arbor, Mich., Ann Arbor Science Publishers, Inc., $1171 \mathrm{p}$.

Delzer, G.C., Zogorski, J.S., Lopes, T.J., and Bosshart, R.L., 1996, Occurrence of the gasoline oxygenate MTBE and BTEX compounds in urban stormwater in the United States, 1991-95: U.S. Geological Survey Water-Resources Investigations Report 96-4145, 6 p.

Fenelon, J.M., and Moore, R.C., 1996, Occurrence of volatile organic compounds in ground water in the White River Basin, Indiana. 1994-95: U.S. Geological Survey Fact Sheet 138-96, 4 p.

Illinois Department of Public Health. 1998, Illinois Water Well Construction Code, 1998: Illinois Department of Public Health, 43 p.

Illinois Environmental Protection Agency, 1991, Groundwater Quality Protection program: Normal facility number
1120900 well site survey report: Springfield, Ill., Illinois Environmental Protection Agency, Division of Public Water Supplies, IEPA/PWS/91-49, 119 p.

Illinois Environmental Protection Agency, 1996, Illinois water quality report, 1994-1995: Springfield, Ill., Illinois Environmental Protection Agency, Bureau of Water, IEPA/BOW/96-060a, $422 \mathrm{p}$.

Kempton, J.P., Johnson, W.H., Heigold, P.C., and Cartwright, Keros, 1991, Mahomet Bedrock Valley in eastcentral Illinois; Topography, glacial drift stratigraphy, and hydrogeology in Melhorn, W.N., and Kempton, J.P., ed., Geology and hydrogeology of the Teays-Mahomet Bedrock Valley System, 1991: Geological Society of America Special Paper 258, p. 91-124.

Koterba, M.T., Wilde, F.D., and Lapham, W.W., 1995, Ground-water datacollection protocols and procedures for the National Water-Quality Assessment program: Selection, installation, and documentation of wells, and collection of related data: U.S. Geological Survey Open-File Report 95-398, 69 p.

Rose, D.L., and Schroeder, M.P., 1995, Methods of analysis by the U.S. Geological Survey National Water Quality Laboratory - Determination of volatile organic compounds in water by purge and trap capillary gas chromatography/mass spectrometry: U.S. Geological Survey Open-File Report 94-708, $26 \mathrm{p}$.

Scott, J.C., 1990, Computerized stratified random site-selection approaches for design of a ground-water-quality sampling network: U.S. Geological Survey Water-Resources Investigations Report 90-4101, 109 p.

Squillace, P.J., Moran, M.J., Lapham, W.W., Price, C.V.. Clawges, R.M., and Zogorski, J.S., in press, Volatile organic compounds in untreated ambient groundwater of the United States, 1985-1995: Environmental Science and Technology.

U.S. Environmental Protection Agency, Office of Underground Storage Tanks, 1998, MTBE Fact Sheet no. 3: Use and distribution of MTBE and ethanol: U.S. Environmental
Protection Agency Publication

EPA 510-F-97-016, 3 p.

U.S. Environmental Protection Agency, Office of Water, 1996, Drinking water regulations and health advisories: U.S. Environmental Protection Agency Publication EPA 822-B-96-002, 16 p.

U.S. Environmental Protection Agency, Office of Water, 1997, Fact Sheet: Drinking water advisory: Consumer acceptability advice and health effects analysis on methyl tertiary-butyl ether (MtBE): U.S. Environmental Protection Agency Publication EPA-822-F-97-009, 4 p.

Warner, K.L., and Schmidt, A.R., 1994, National Water-Quality Assessment Program - The lower Illinois River Basin: U. S. Geological Survey Fact Sheet 94-018, 2 p.

\section{FOR MORE INFORMATION}

For information on USGS programs and activities in Illinois, please visit our Web site at

http://il.water.usgs.gov

or contact

District Chief

U.S. Geological Survey 221 North Broadway Avenue Urbana, IL 61801

Telephone: 217.344 .0037 email: dc_il@usgs.gov

Additional earth science information can be found by accessing the USGS Home Page at

\section{http://www.usgs.gov}

For information on all USGS

products and services,

call 1.888.ASK.USGS

FAX: 703.648 .5548

or email: esic@usgs.gov 